\section{British Association adapts to its higher political profile}

\section{London}

VyING for media attention with the Edinburgh festival (of the arts), this year's gathering of the British Association for the Advancement of Science (BA) has a familiar look. Matters of moment will be aired - with the Right Reverend Hugh Montefiore sure to attract attention by restating the value of chastity in the control of AIDS (acquired immune deficiency syndrome) when the topic is covered in this year's 'BA Debate'. Elsewhere, amateur astronomers and dinosaurwatchers are well catered for and local interests are well served - with 'The Spanish Armada and Ireland' a highlight to coincide with the Armada's imminent 400th anniversary.

But the present mood in the scientific profession in the United Kindom, exemplified by the steady progress of the Save British Science pressure group, has given a sense of purpose to the BA that seemed lacking in the past. Opening proceedings (this year at Queen's University, Belfast) earier this week, BA president Sir Kenneth Durham set the agenda for a year of campaigning aimed at the "apathy of the general public towards science", which, he says, is "reflected in, and indeed compounded by, attitudes of some businessmen, academics and scholars - people at the front-end of their professions"

The BA's new-found evangelical approach is likely to mean a more 'political' stance from now on. During the recent general election, Durham wrote to the party leaders asking their views on the importance of science to the national economy. The replies were "unenlightening", says Durham, who adds that during the election campaign he heard no party talk about research "except in the most general and vague terms". There were, he says, a few mentions of "the need for more investment in development", but these "missed almost entirely the point that development is dependent on fundamental research".

Industry, says Durham, "has been slow to come to terms with the rate of technical change, and has not played a sufficiently constructive role in linking with education in the past". Durham detects signs of improvement, however, and can even be positive about the much-maligned financial institutions in the City - "the perceived short-term approach of the City and industry to investment is changing and longer-term investment policies are beginning to emerge".

So the public and industry are to be targeted in the BA's campaign - which will depend on additional funding to be sought from industry to support a new 'corporate plan' — but the non-interventionist polices of the government are also to be tackled. Industry should find development ("the most expensive part of the science and technology spectrum") but government, says the BA president, "should concentrate on those research projects likely to be important to the country but unlikely to be funded by industry"

Later this week, during the sessions entitled "Science Audit", more ammunition for the BA campaign should emerge.

Charles Wenz

\section{Voyager's tenth birthday}

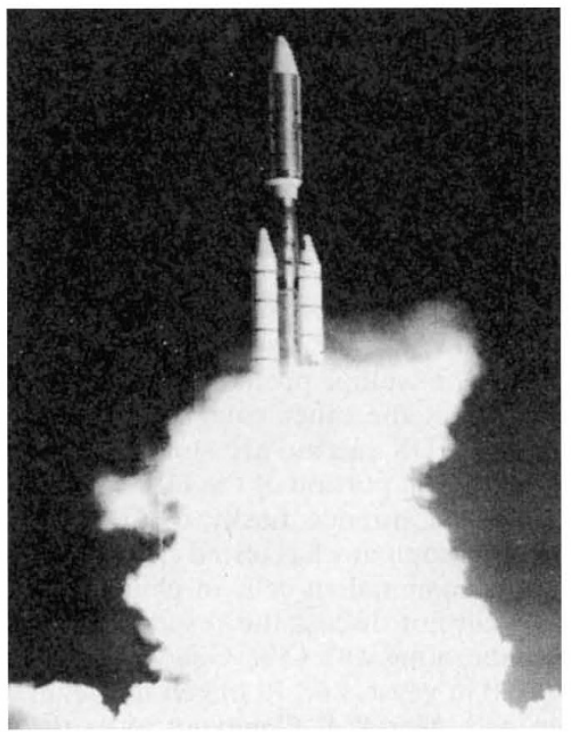

IF other parts of the US space programme are having problems, there is at least one mission NASA (National Aeronautics and Space Administration) can crow about. The space agency is celebrating the tenth anniversary of the two Voyager planetary probes, and although Voyager 1's mission is essentially complete, Voyager 2 still has a planet to visit.

Voyager 1 (above) left Earth on 5 September 1977. Voyager 2 left a little earlier, on 20 August. The two spacecraft visited both Saturn and Jupiter, taking advantage of a rare alignment that permitted the planetary 'tours'. At Saturn, Voyager 1 left the plane of the ecliptic, but Voyager $\mathbf{2}$ used Saturn to change its velocity and head for Uranus. The Uranus encounter took place in January 1986, and there too Voyager 2 took advantage of local gravity to change its trajectory, this time aiming for Neptune. Voyager's closest approach to Neptune will occur on 24 August 1989.

The Voyager programme was intended to end with the Saturn flybys in 1980 and 1981 , but the success of those encounters prompted NASA to keep it going. Through some clever reprogramming of its onboard computers, Voyager 2 has been able to keep up a stream of data, and has already sent back its first picture of Neptune, still some 1,400 million $\mathrm{km}$ away.

\section{Fang Lizhi "no Sakharov"}

\section{London}

FANG Lizhi, the former vice-rector of China's University of Science and Technology, has repudiated suggestions that he is the "Chinese Sakharov". Last January, Fang was relieved of his university post and expelled from the Communist Party for allegedly having encouraged his students' demands for "bourgeois liberalization". But, as Fang stressed in an interview published last month by the Hong Kong journal Cheng Ming, there is an important difference between Sakharov and himself. He, Fang, is not "isolated". On the contrary, since he was expelled from the party he has received many letters "from all directions and from different social strata", letters which, he implied, were supportive.

Fang gave his interview in Rome, where he had been attending a meeting on astrophysics. The fact that, although in disgrace with the party, Fang has been allowed to continue his scientific career (he now has a post at the Chinese Academy of Sciences' Beijing University), is frequently cited by the Chinese establishment as an example of the new democratization of science. (Such claims ignore the fact that Fang has been refused permission to attend conferences in the United States and United Kingdom.)

Fang's own comments on the situation, however, although guarded, are less happy. "If you are repudiated by the party", he said, "you have only the freedom to confess your fault, but no right to refute criticism against you". So far, he said, he has not made any self-criticism, but "you cannot say that there is no pressure on me". Nevertheless, he added, the pressure has been less than "people abroad have expected".

Fang is clearly trying to take an optimistic view of his situation. He believes that by continuing scientific research he can help to hasten democratization. Science, he said, cannot develop without democracy.

China, Fang said, is now facing a "sociological Planck effect". The older generation cannot be expected to change its views, but, as in the case of Planck's constant, the ideas of democracy will ultimately be accepted when the older generation have all died. His own error, he considers, was not that of being a "Chinese Sakharov", but a "Chinese Marco Polo". Marco Polo's descriptions of the Orient, he explained, were disbelieved as travellers' tales. Likewise, he, Fang, had been accused of talking nonsense when he tried to introduce "the $\mathrm{ABC}$ of the West" into China. Vera Rich 